\title{
Det muliges kunst. Om betingelserne for det tværsektorielle samarbejde i et New Public Management- orienteret sundhedsvæsen
}

\section{Ditte Høgsgaard}

Trods tidens idé om at samarbejde og kommunikation på tværs af det danske sundhedsvæsens sektorer er afgørende for at skabe et sammenhængende sundhedsvæsen, synes de institutionelle rammer og betingelser i dag at spænde ben for et sådant samarbejde. En stærk diskurs om nødvendigheden af et velfungerende tværsektorielt samarbejde lever isoleret fra - og udfordres grundlæggende af den 'New Public Management' logik, der har præget de seneste årtiers styring og organisering af sundhedsvæsenet. Med udgangspunkt i to fortællinger fra et gennemført aktionsforskningsprojekt viser jeg, hvorledes spændinger og paradokser i det tværsektorielle samarbejde på en gennemgribende facon påvirker de sundhedsprofessionelles arbejdsvilkår og deres muligheder for at samarbejde tværsektorielt om ældre patienters udskrivelse fra hospitalet.

\section{Indledning}

"Evalueringen af kommunalreformen viser, at den nuvaerende opgavefordeling $i$ sundhedsvoesenet fungerer godt, men at der på en roekke områder er behov for at styrke indsatsen og samarbejdet på tvaers af sektorer" (Regeringen 2013, 3).

$\mathrm{D}$ ette indledende citat viser, at den socialdemokratiske regering i 2013 havde et ønske om at styrke det tværsektorielle samarbejde, et ønske, der også følges op af den borgerlige regering med sundhedsministerens udtalelse i 2016:

\begin{abstract}
"Alle patienter skal opleve sammenhoeng $i$ deres behandlingsforløb på tvoers af sygehuse, kommuner og praktiserende loeger, men det sker ikke altid $i$ øjeblikket. Derfor er der behov for, at vi ser på, hvordan vi kan gøre samarbejdet mellem aktørerne endnu bedre (...) siger Sophie Løhde" (Sundheds- og Ældreministeriet 2016).
\end{abstract}

I begge citater, og i andre centrale og aktuelle danske policy dokumenter, fremhæves idéen om, at et sammenhængende sundhedsvæsen kan skabes gennem et velfungerende tværsektorielt samarbejde ${ }^{1}$ (se fx Danske Regioner 2015; KL 2012; 2015). Med 
inspiration fra Carol Bacchi's analytiske begreb: 'What's the problem represented to be?' (WPR) er det interessant at se på, hvilket problem der egentligt repræsenteres i de to citater. Bacchi fremhæver, at:"... since all policies are problematizing activities, they contain implicit problem representations" (Bacchi 2009, 2). Der er således, ifølge Bacchi, i måden problemet beskrives på ofte en implicit forståelse af, hvad løsningen af 'problemet' er, og hvad, der bør gøres. I første citat er problemet, at indsatsen og samarbejdet i mellem sektorerne ikke er godt nok - det skal styrkes. I det andet citat er problemrepræsentationen, at patienterne ikke oplever sammenhæng i deres behandlingsforløb. I begge citater peges på samme løsning: Indsatserne skal fokusere på at styrke samarbejdet mellem sektorernes aktører. Problemet er således tæt knyttet til en præmis om, at det er samarbejdet mellem aktørerne i sundhedsvæsenet, som er problemet. Hvis aktørerne bliver bedre til at samarbejde, bliver problemet løst, og så vil patienterne kunne opnå idealet om at få et sammenhængende behandlingsforløb. Men, som Bacchi også fremhæver, hvad er tavst? Og hvad problematiseres ikke ved problemrepræsentationen? (Bacchi 2009, 12). Det, som jeg ser forbliver tavst i de to citater og i min læsning af andre policy dokumenter (fx: Danske Regioner 2015; Indenrigs- og Sundhedsministeriet 2007; Indenrigsministeriet 1977; 1985), er betydningen af sektorernes forskellige former for viden og magt og de institutionelle rammer og betingelser for det tværsektorielle samarbejde.

I denne artikel problematiserer jeg idéen om, at der kan skabes et sammenhængende sundhedsvæsen ved alene at styrke indsatsen. I regioner og kommuner har man hidtil forsøgt at løse problemet, bl.a. ved at sende medarbejderne på kommunikationskurser, der skal forbedre den enkeltes kompetencer (Høgsgaard 2016). Ved at fokusere på de sundhedsprofessionelles kompetencer og ikke de institutionelle rammer gøres problemet til medarbejdernes personlige problem. Mit argument er, at sektorernes forskellige former for viden og magt og de institutionelle rammer har en afgørende betydning for, hvordan det overhovedet er muligt for de sundhedsprofessionelle på tværs af sektorerne at samarbejde om at skabe et sammenhængende forløb for patienterne. I min forståelse af begreberne 'viden', 'magt' og 'institutionelle rammer' trækker jeg på Michel Foucaults tænkning om, at der i de institutionelle rammer er indlejret særlige måder at kunne forstå og handle på, som betinger konkrete magtrelationer (Foucault 2012). Mit afsæt for at forstå, hvad der for de sundhedsprofessionelle er relevant og magtfuld viden, tager afsæt i et foucaultdiansk perspektiv, hvor viden og magt ikke kan forstås uafhængig af den institutionelle kontekst (Foucault 1972; 2012). Med dette afsæt viser jeg, hvordan de institutionelle rammer har betydning for, hvad og hvordan det tværsektorielle samarbejde kan sprogliggøres, forhandles og praktiseres af de sundhedsprofessionelle.

Det er mit overordnede formål i denne artikel at vise de arbejdsmæssige konsekvenser af, at det tværsektorielle samarbejde foregår i en spoending mellem på den ene side idéen om et sammenhængende sektorsamarbejde til gavn for patienter og borgere, og på den anden side nødvendigheden af at kunne samarbejde om patienten og borgeren ud fra de specifikke institutionelle rammer, som et sektoropdelt og New Public Management-orienteret (herefter NPM) sundhedsvæsen er underlagt. Med afsæt i analyser af to fortællinger fra et gennemført aktionsforskningsprojekt viser jeg, hvordan aktørernes forskellige former for viden og magt og de institutionelle rammer genererede spændinger og paradokser, som 
havde afgørende betydning for det tværsektorielle samarbejde.

Jeg indleder artiklen med et afsnit, hvor jeg placerer artiklen i forhold til studier af NPM. Herefter udfolder jeg artiklens teoretiske afsæt i governmentality-studier af selvledelse, og de analytiske nedslag dette giver anledning til. Dette efterfølges af en præsentation af min metodiske tilgang og det empiriske materiale. Endelig problematiserer jeg, gennem en analyse af aktørernes sprogliggørelse og handlinger, hvordan de institutionelle rammer, magt og vidensformer aktivt modarbejdede det tværsektorielle samarbejde og resulterede i et belastende og stressende arbejdsmiljø for medarbejderne.

\section{Et NPM-orienteret sundhedsvæsen}

NPM har som en global styringstendens det formål at øge markedsstyring og management-orientering i den offentlige sektor (Hood 1991). Inden for en NPM-tænkning er formålet bl.a. at skabe hurtigere og bedre patientforløb for færre ressourcer gennem privatisering og gennem diverse effektiviseringsstrategier. Implementeringen og de seneste årtiers påvirkning af NPM strategier, har således også haft betydning for de sundhedsprofessionelles arbejdsmiljø og arbejdsliv i det danske sundhedsvæsen (se fx Dahl 2004; 2009; Hasle 2014; Kamp et al. 2013; Møller 2014). Desuden har strukturreformen fra 2007 haft betydning for omorganisering og styring af de professionelles arbejde i den offentlige sektor. Strukturreformen betød, at 271 kommuner blev sammenlagt og omdannet til 98 kommuner, og at 14 amter blev nedlagt, og i stedet blev der skabt fem regioner (Indenrigs- og Sundhedsministeriet 2004). I både kommuner og regioner har strukturreformen medført et øget fokus på standardisering, priva- tisering og kvalitetssikring af de offentlige opgaver. Der er ligeledes indført nye styringsredskaber som Lean, kvalitetsreformer med akkrediteringssystemer i regionerne - og 'Bestiller og Udføre Modellen' (BUM) i kommunerne (Poulsen 2002). Hensigten med disse styringsredskaber er, at de skal biddrage til en mere effektiv og rationel styring af sundhedsvæsenet. NPM tager afsæt i neoliberale værdier om et åbent og individualiseret marked, hvor offentlige ydelser skal kunne udveksles som varer, tælles, opsplittes, prissættes, købes og sælges gennem partnerskaber og kontrakter. I denne tankegang bliver patienter og borgere i høj grad opfattet som kunder og klienter (Busch et al. 2005; Greve 2003). I den kommunale ældrepleje har introduktionen af NPM-tankegangen også betydet, at de sundhedsprofessionelle skal håndtere en stram målstyring, privatisering, indgå i kontraktforhold med borgerne samt arbejde med at standardisere arbejdsopgaverne (Dahl 2009; Kamp et al. 2013; Møller 2014). Denne måde at styre på er forskellig fra tidligere, hvor den kommunale hjemmepleje ud fra professionsfaglige idealer og inden for de budgetmæssige rammer selv kunne sætte standarder og organisere arbejdet. I hospitalssektoren har NPM ligeledes haft en gennemgribende betydning for organiseringen af de sundhedsprofessionelles arbejde. Dette har betydet et øget fokus på effektivitet og standardisering, bl.a. ved indførelse af IT-systemer (Seemann, Gustafsson \& Dinesen 2011, 2). Især har introduktionen af Lean-redskaber på de danske hospitaler siden 00'erne haft en central betydning for organisering og styring af medarbejdernes arbejde og dermed betydning for deres arbejdsliv (Hasle 2014, 69). Der er altså både i kommunalt og hospitalsregi sket en forskydning af styringsformer fra en decentralisering til centralisering.

Jeg vil i nærværende artikel vise, at den- 
ne NPM orientering ikke kun har skabt en række administrative udfordringer, idet administrationen nu skal forholde sig til centralt fastsatte styringsformer, men at det ligeledes har haft en mærkbar indflydelse på de sundhedsprofessionelles arbejdsforhold og deres reelle muligheder for at kunne samarbejde tværsektorielt.

\section{Metodologi}

Artiklens analysemateriale er genereret i et tværsektorielt aktionsforskningsprojekt. Aktionsforskningsprojektet havde fokus på at forbedre de sundhedsprofessionelles tværsektorielle samarbejde og kommunikation i forbindelse med ældre patienters udskrivelse fra hospital til eget hjem (Høgsgaard 2015). Projektets teoretiske og metodiske afsæt var aktionsforskning (Coghlan \& Brannick 2014; Reason \& Bradbury 2008; Svensson \& Nielsen 2006), og gruppen arbejdede ud fra en kollaborativ demokratisk 'bottom up'-tilgang (Svensson \& Nielsen 2006; Phillips et al. 2013). Aktionsforskningsprojektet var ligeledes inspireret af en poststrukturalistisk forståelse af praksis som en diskursiv praksis, der inkluderer og ekskluderer bestemte måder at forstå og agere i praksis på (Foucault 1972; 1980). Især var aktionsforskningsgruppen optaget af at undersøge, hvordan forskellige former for viden, magt og institutionelle rammer havde betydning for de sundhedsprofessionelles muligheder for at samarbejde og kommunikere om patienters udskrivelse på tværs af sektorerne i sundhedsvæsenet.

Aktionsforskningsforløbet varede ét år fra 2014 til 2015. Deltagerne var medarbejdere (sygeplejersker, social- og sundhedshjælpere og -assistenter, ledere, fysioterapeuter og ergoterapeuter) fra et kommunalt hjemmeplejeområde og en hospitalsafdeling i Danmark. Aktionsforskningsforløbets start var tre tværsektorielle workshopdage, hvor der pr. gang deltog 12-14 medarbejdere med forskellige faglige baggrunde. Hovedformålet var at få deltagernes forskellige forståelser og viden om det tværsektorielle samarbejde om patienters udskrivelse frem og dermed definere aktionsforskningsprojektets konkrete problemstilling. Centrale pointer fra de tre workshop dannede således afsæt for aktionsforskningsgruppens arbejde. Aktionsforskningsgruppen bestod af tre sundhedsprofessionelle fra hver sektor og mig selv som ph.d.-stipendiat. Gruppen arbejdede sammen i otte 'fællesdage' over en $3 / 4$ årig periode. Imellem aktionsforskningsdagene arbejdede aktørerne også med at afprøve forskellige initiativer i egen praksis. Forløbet blev afsluttet med en evalueringsworkshop. Måden vi arbejdede på var inspireret af en kritisk utopisk aktionsforskningstilgang (Svensson \& Nielsen 2006) af fremtidsværksted modellen (Jungk \& Müllert 1984), og vi arbejdede med forskellige dialogiske metoder: fortællinger (Taylor 2009), billedanalyse (Hee Pedersen 2008) og reflekterende teams (Andersen 1987). Desuden gennemførte vi en lokal spørgeskemaundersøgelse og et fokusgruppeinterview (Halkier 2010). Aktionsforskningsgruppen analyserede i fællesskab det empiriske materiale og udviklede og afprøvede forskellige initiativer i praksis, fx fx etablering af tværsektorielle og tværfaglige udvekslingsforløb for medarbejderne, etablering af tværfaglige konferencer, introduktion af forslag til en tværsektoriel ekspertperson og udarbejdelse af et introduktionsprogram til alle nye medarbejdere om det tværsektorielle samarbejde i forbindelse med ældre patienters udskrivelse (Høgsgaard 2015).

Aktionsforskningsprojektet genererede udover de konkrete forslag til aktioner, også viden om, hvordan medarbejdere, som arbejder tværsektorielt med at udskrive ældre patienter, både forstår og arbejder med 
problemstillingen. Gennem aktionsforskningsprojektet blev det tydeligt, at de institutionelle rammer på flere områder viste sig at være en hindring for det tværsektorielle samarbejde. Det er denne fælles vidensproduktion om betydningen af de institutionelle rammer, som er det empiriske af sæt for denne artikel. På baggrund af dette empiriske afsæt har jeg konstrueret to fortællinger om den fiktive ældre patient Gerda Hansens udskrivelse fra hospitalet til eget hjem. Jeg har med inspiration af etnografisk narrativ metode fremstillet analysematerialet ud fra det, Holliday (2016) og Agar (1990) benævner som 'creative nonfiction'. Ved at bruge denne fortælleform rekonstrueres det empiriske materiale, og jeg lader som 'forfatter' centrale fremanalyserede pointer træde frem. Formålet med at anvende denne metode er "...to demonstrate "how pattern is grown to enable comprehension of member-produced social action in the context of one world from the perspective of another"(Agar 1990, 86). In this sense, the creative nonfiction narrative is not in itself a form of data but the result of analysis" (Holliday $2016,148)$. Som 'forfatter' viser jeg situationer, der er genskabt for læseren, så hun/ han kan se, høre, smage og mærke, lytte til dialogen og føle den emotionelle tone, og som Agar fremhæver: "..the scenes are real, not imagined" (Agar 1990, 77). De to fortællinger repræsenterer analyseelementer fra både de tre workshops og aktionsgruppens arbejde, ligesom min deltagelse i projektet og min insiderviden som tidligere sygeplejerske også har haft betydning for fremstillingen af fortællingerne. Fortællingerne er således analyser, der repræsenterer deltagernes repræsentationer. Der er et slags dobbelt repræsentationsarbejde på spil, som udfordrer forestillingen om repræsentationer som afspejlinger af 'virkeligheden'. At lade analysen være repræsenteret igennem fortællingerne giver mig også en mulighed for at anonymisere deltagerne (Holliday 2016, 148), som er en velkendt udfordring i aktionsforskningen (Coghlan \& Brannick 2014; Neidel 2011)col-lect and analyse data and report results (Sagor 1992. Som Skrubbeltang fremhæver i sin ph.d.-afhandling om korrespondenters arbejde i Mellemøsten, har hans konstruktion af fortællinger om to fiktive korrespondenter givet mulighed for at fremhæve situationer og hændelser, der var svære at anonymisere (Skrubbeltang 2014, 74 ff). Jeg forsøger med de to fortællinger at fremstille aktionsforskningens centrale pointer, velvidende at det er min fortolkning både som deltager og forsker, der kommer til udtryk. Det er ikke et forsøg på at fremstille den typiske sygeplejerske eller visitator, men at fokusere på, hvordan de gennem selvledelse agerer i de to fortællinger. Fortællingerne er i forbindelse med denne artikel præsenteret for og kommenteret af deltagerne i aktionsforskningsgruppen. Deres respons var, at begge fortællinger var 'spot on' i forhold til deres erfaringer. Fortællingerne fremstår dermed ikke som min konstruktion alene. Det er dog mig som forfatter, der har truffet beslutning om,og taget initiativ til at konstruere de to fortællinger som en metode til at udfolde en række analytiske pointer omkring samarbejde, spændinger og arbejdsforhold i tværsektorielt samarbejde.

\section{En analyse af selv-ledelse i det tværsektorielle samarbejde}

I denne artikel trækker jeg primært på Michel Foucaults senere forståelse af viden og magt, hvor han især er optaget af styring forstået som 'governmentality' (Foucault 1982, 2014; Rose \& Miller 1992). Magt knyttes hos Foucault, og især i hans idéer om governmentality, sammen med en styringsrationalitet, hvor menneskers handlemuligheder bliver til i sociale magtrela- 
tioner, der styres og reguleres gennem en form for subjekt-selv-ledelse. Det betyder "... at selvet og subjektiviteten konstitueres $i$ magtrelationer og forskellige styreformer, dels diskursivt i form af videnskabelige teorier, dels praktisk i form af teknologier, der udvikles i forskellige institutioner" (Otto 2003, 1). Med et governmentality-inspireret analytisk blik bliver jeg optaget af at se på, hvordan styring af medarbejderne, gennem deres egen selvledelse, træder frem i det tværsektorielle samarbejde. Governmentality-teoretiker, Mitchell Dean, fremhæver hertil, at styring og selvledelse sker gennem styringsteknologier og -teknikker, som fordrer en eksplicit politisk rationalitet, og som både styres i det praktiske sprog og gennem en teknisk praktisk side (Dean 2002). Teknologier skal med Dean forstås som komplekser af viden, der er strategisk rettede mod at frembringe bestemte mål. Fx er NPM en styringsteknologi, der har sit eget sæt af forståelser og strategier, som gennem effektivitetsprocesser skal føre til målet øget markedsorientering i den offentlige sektor. Teknikker ses som de initiativer, systemer og rammer, der har til formål at forme og forandre den enkeltes evner for at kunne agere 'rigtigt' i sit eget liv - arbejdsliv. Det betyder, at de sundhedsprofessionelle, for at kunne handle rigtigt, er nødt til at have fokus på, hvordan de kan handle effektivt og standardiserende i forhold til den ældre patients udskrivelse. At undersøge praksis er derfor at se på, hvordan subjekter i sprog og handling repræsenterer bestemte teknologier og teknikker (Dean 1994). For at kunne sige noget om de måder, hvorpå magt, viden og institutionelle rammer får betydning for de professionelles selv-ledelse i det tværsektorielle samarbejde, ser jeg derfor i denne artikel på, hvordan det tværsektorielle samarbejde repræsenteres på to måder. Med inspiration fra Foucaults governmentality-tilgang analyserer jeg de to fortæl- linger. Først med fokus på, hvordan spændinger, som de to fiktive medarbejdere stod overfor, fik betydning for deres tværsektorielle samarbejde om patientens udskrivelse. Spændingsbegrebet henter jeg fra Phillips (L. J. Phillips 2011; L. Phillips 2011; Phillips et al. 2013). Jeg ser spændinger som et åbent begreb, der anerkender forskellighed som en dynamisk grænse. Spændinger skal således ikke forstås som noget konfliktfyldt eller som en barriere for at kunne dele forståelse, men som et dynamisk begreb, der kan bidrage positivt til meningsdannelse - og som bygger på detaljeret analyse af, hvordan spændingerne er tilkendegivet i samspillet mellem de kæmpende diskurser (L. Phillips 2011). Derefter fokuserer jeg på, hvordan de sundhedsprofessionelle i deres sprog og handlinger repræsenterede bestemte selvledelsesteknologier og -teknikker, som medvirkede til at reproducere og transformere de institutionelle rammer. På baggrund af disse to analysegreb diskuterer jeg afslutningsvis, hvilke paradokser i det tværsektorielle samarbejde mine analyser peger på, og hvordan paradokserne har betydning for de sundhedsprofessionelles handlemuligheder.

\section{To fortællinger om spændinger i samarbejdet omkring en ældre patients udskrivelsesforløb}

De to fortællinger handler om Gerda Hansen på 92 år, der skal udskrives efter kort tids indlæggelse på hospitalet på grund af mistanke om lungebetændelse. Den første fortælling viser de spændinger, som hospitalets sygeplejerske (Trine) oplever i forbindelse med patientens udskrivelsessituation. Den anden fortælling viser spændinger, som den kommunale visitator, social- og sundhedsassistent (Ole) står i, når Gerda Hansen skal modtages i hjemmeplejen efter 
to dages indlæggelse på hospitalet og skal have genoptaget sin hjælp fra kommunen.

\section{En fortælling om udskrivelse af en ældre patient}

Trine er sygeplejerske og møder ind på afdeling $X$ efter to fridage. Hun kan se, at hun ikke kender nogen af patienterne i sin gruppe. Der er et rødt moerke ud for tre patienter. Det betyder, at de skal udskrives $i$ dag. Hun håber, at kommunen er adviseret om udskrivelserne, ellers bliver det svaert at nå dem i dag. Heldigvis er de på afdelingen blevet meget bedre til at advisere kommunen med en foreløbig udskrivelsesplan. Det gør de hellere en gang for meget, end en gang for lidt. Så kan de altid aflyse udskrivelsen, hvis patienten alligevel ikke skal hjem. Hun håber, at loegen kommer på stuegang tidligt, så han kan tage endeligt stilling til patientens udskrivelse, og hun kan nå at sende den elektroniske plan til visitatoren inden $k l$. 13. I sidste uge fik hun en ubehagelig overfusning af en af overloegerne, fordi hun ikke havde fået udskrevet en patient inden $\mathrm{kl}$. 13. Hun oplever, at det giver en dårlig stemning, ligesom hun finder, det er urimeligt, at hun får ballade, fordi det er svoert at overholde tidsrammen, og fordi kommunen ikke er klar til at tage patienten hjem hurtigt nok. Trine oplever tit, at det er en kamp mellem hende og visitatoren fra kommunen. Det er som om, visitatoren giver hende skylden for, at patienterne skal udskrives hurtigt. Som om det er hendes problem, at der ikke plads til patienterne nogen steder. På afdelingen er de blevet mere pressede, efter de har fået indfort Lean. Hun synes, det er nogle moerkelige opgaver, de bliver målt på. Trine ser, at det er $i$ dag, der skal voere Lean-tavlemøde. Hun håber ikke, at hun bliver udtaget til at forklare, hvorfor hun valgte at fravige bos-målingerne hos en af patienterne $i$ sidste nattevagt. Hun loeser den elektroniske journal om Gerda Hansen og toenker, at Gerda måske ikke er helt klar til udskrivelse, selvom blodprøverne er normale. Det er tredje gang, Gerda er indlagt inden for et halvt år, måske fejler hun noget andet? På hospitalet har de bare ikke tid til at se på andre sygdomme end den, patienten er indlagt med. Det ville hun ønske, at de kunne. Trine har prøvet at foreslå, om de ikke skulle undersøge patienten yderligere, men beskeden fra stuegangsloegen var, at hvis patienten fejler andet end det, han eller hun er indlagt med, så må de henvende sig til egen loege. Klokken er 12:30, og Trine er klar til at melde Gerda hjem. Hun har udfyldt det elektroniske udskrivelsesnotat. Hun har stadig ikke voennet sig til, at informationen om patientens indloeggelse skal stå $i$ helt faste rubrikker, og at der kun er plads til et bestemt antal tegn $i$ hver rubrik. Hun synes, det begroenser kommunikationen, men afdelingen skal snart akkrediteres, så det er vigtigt, at al dokumentationen er i orden. Notatet om udskrivelsen sendes elektronisk, og det er egentlig ikke meningen, at hun skal tale med visitatoren overhovedet. Men visitatoren ringer tit for at få uddybet notatet. Det er enormt forstyrrende og tidsrøvende. Hun føler også tit, det er ubehageligt at tale med visitatoren, fordi hun ikke selv kender patienten godt nok til at kunne svare på alle spørgsmålene. Tit spørger visitatoren om alt muligt andet, fx.: "Hvordan er boligforholdene hos patienten hjemme, og hvordan det går med patientens andre lidelser?" Trine synes, mange af visitatorens spørgsmål er irrelevante, og i virkeligheden kender de jo i kommunen patienten bedre, end hun gør. Nogle gange er det som om, de helst ikke vil have patienten hjem. Hun ved da godt, at de også er pressede i kommunen, men hun føler sig tit mistaenkeliggjort af deres spørgsmål. Som om hun gør patienten bedre, end hun eller han er. Ok, det gør hun faktisk også nogle gange, fordi det er vigtigt hurtigst muligt at få patienten ud af afdelingen, selvom hun godt ved, at patienten måske ikke altid er klar, og at en ekstra dag ville gøre undervaerker. Nogen gange er de faktisk helt oppe i det røde felt, når de taler sammen. Det er egentlig ikke rimeligt for nogen af parterne. De gør jo bare deres arbejde. 


\section{Spændinger i sygeplejerskens arbejde med udskrivelsen}

Ved patientens udskrivelse er sygeplejersken presset på tid, fordi hun skal overholde de deadlineaftaler, der er indgået mellem region og kommune i forbindelse med patienternes udskrivelse (Ministeriet for Sundhed og forebyggelse 2010). Det er aftaler, som kan være svære for hende at overholde, fordi hendes arbejde også er betinget af, om fx lægen og kollegaerne har gjort deres del af arbejdet, så hun kan nå at udskrive patienten inden kl. 13. At overholde tidsrammen er altså en væsentlig del af at udskrive patienten, som udfordres af organiseringen af arbejdet på sygehuset, fx om lægen kan nå at udskrive tidsnok, og om kollegaerne har adviseret kommunen i tide. Det viser, at regionsaftalen ikke blot griber ind i det direkte tværsektorielle samarbejde, men også i det interne samarbejde på sygehuset. Sygeplejersken forsøger at få det til at glide og at skaffe sig mere tid ved at udskrive patienten 'i systemet', selvom patienten endnu ikke er helt klar til udskrivelse. Hun handler ikke imod reglerne ved at fremskynde et udskrivelsestidspunkt, selvom hun ved, at det betyder ekstra arbejde i kommunen, og at det er åbenlyst ressourcespild. Der er altså en spænding imellem arbejdets organisering på sygehuset og de krav, sundhedsaftalen stiller om at overholde bestemte deadlines i udskrivelsesproceduren.

En anden spænding, som kommer frem $i$ fortællingen, handler om, at det alene er patientens indlæggelsesdiagnose, som berettiger indlæggelsen på hospitalet og ikke en vurdering af patientens samlede situation. I fortællingen overvejer Trine at inddrage betydningen af Gerda Hansens øvrige lidelser i vurderingen af, hvorvidt hun er klar til udskrivelse. Men det bliver umuligt for hende, fordi det er den sygdom, som patienten indlægges med, der berettiger patientens plads på hospitalet - og som der- med også afgør, hvornår patienten er klar til udskrivelse. Det er således en spænding mellem på den ene side et diagnose-orienteret sundhedsvæsen og på den anden side hensynet til, hvad der er bedst for patienten, som er en central del af den overordnede politiske strategi (Regeringen 2013a;2013b; Sundheds- og Aldreministeriet 2016).

Der er ligeledes en spænding imellem sygeplejerskens oplevelse af på den ene side at blive anerkendt af sin leder for at følge standarder, målinger og regler - og på den anden side at have et ønske om at gennemføre et tværsektorielt samarbejde, der tilgodeser patientens samlede situation. Det bliver til en spænding, fordi sygeplejersken primært anerkendes af sin leder og lægen for at udskrive patienten hurtigt, overholde regler og standarder og at bruge sin tid på at foretage Leanstyrede målinger, fremfor at prioritere det tværsektorielle samarbejde og kommunikationen med visitatoren omkring den enkelte patient. Sygeplejersken kan dermed opleve samarbejdet og kontakten med visitatoren som forstyrrende indgriben i sit arbejde på sygehuset, idet hun netop ikke anerkendes for dette tværsektorielle samarbejde, som tillige tager hendes tid.

Der er ligeledes spændinger knyttet til sygeplejerskens samarbejde med lægen og visitatoren. Trine oplever en dårlig stemning på arbejdet, når hun overfuses af overlægen og visitatoren, når hun "føler sig mistoenkeliggiort", og når alle er "oppe i det røde felt". Det er nærliggende her at se på, hvordan retten (magten) til at definere, om patienten kan udskrives/modtages i hjemmeplejen, bliver til. Det er en spænding, som er knyttet til det, som Jespersen beskriver som et brud med de historiske magtpositioner i sundhedsvæsenet, der udfordres af NPM (Jespersen 2005). Lægen og hospitalet er nu også underlagt regionsaftalerne, hvor de tidligere havde større autonomi og autoritet i forhold til alene at beslutte, om pa- 
tienten var klar til udskrivelse. Visitatoren har derimod gennem sundhedsaftalen fået en formel magt, som han forsøger at håndhæve, men fordi de "på hospitalet ikke altid kender til sundhedsaftalen", er det vanskeligt for ham også at få den reelle magt. Det giver spændinger i samarbejdet og opleves af begge parter som utilfredsstillende.

Sygeplejerskens og visitatorens forståelse af, hvilken viden der er vigtig, er forskellig og konstrueres i historien som inkompatible. De har vanskeligt ved at forstå hinandens rationaler, ligesom de informationer de udveksler i det elektroniske IT-system ikke er fyldestgørende eller giver mening for den anden part. Spændingen består i, at sygeplejeplejersken af visitatoren stilles til regnskab for sin viden om patientens hjemmesituation og samlede sygdomssituation, en viden hun ikke har - og som ikke er nødvendig for hende på hospitalet for at kunne udskrive patienten. Hun skal derimod kunne beskrive sygdomsforløbet i forudbestemte kolonner, som ikke giver mening for visitatoren.

\section{En fortælling om visitatorens modtagelse af den ældre patient $i$ hjemmeplejen}

Ole har vagten $i$ visitationen. Han toenker, at det bliver en lang vagt med mange udskrivelser. Sådan er det tit om tirsdagen. Det virker som, at det er den dag, hvor de på hospitalet forbereder udskrivelsen af flest patienter. Det betyder, at de i visitationen modtager en masse foreløbige udskrivelsespapirer. Det giver et stort arbejdspres, isoer fordi en stor del af udskrivelserne efterfølgende aflyses, fordi borgeren alligevel ikke er foerdigbehandlet. Det ved Ole godt, men $i$ visitationen er de nødt til at handle på den foreløbige udskrivelsesplan. Han synes, det er meningsløst, og det giver ekstra arbejde. Men det står der $i$ den regionale sundhedsaftale, at de skal. Aflysning kan også betyde, at den madudbringning, der er bestilt ved den private leverandør, må aflyses. Det skal kommunen så betale for, og det synes han er spild af penge. Ole ser på bunken, han har printet ud. Den første handler om Gerda Hansen på 92 år. Ole kender hende ikke. Det er ikke ham, der er hendes faste visitator. Det er svoert at finde hoved og hale i beskeden fra hospitalet. I systemet står beskeden med meget lille skrift, og det er faktisk nogle gange helt umuligt at tyde, hvad der står. Der står, hvilken dag Gerda er blevet indlagt, og at hun er blevet unders $\emptyset$ gt for en lungebetoendelse, som hun ikke havde, så hospitalet vil udskrive hende til vanlig hjoelp i kommunen. Ole synes, at informationerne er mangelfulde. Isaer mangler han informationer om, hvordan Gerda reelt har haft det under indloeggelsen. Har hun kunnet spise selv, tage tøj på, og kunne hun selv klare toiletbesøg? Har hun mon andre sygdomme, og har hun selv styr på sin medicin? De har godt nok udfyldt den kolonne i det elektroniske system, der handler om Gerdas funktionsniveau. Men det er ikke de samme niveaubeskrivelser, som de bruger i kommunen. Ofte er det Oles fornemmelse, at de fra hospitalet siger, at patienten er bedre, end hun eller han faktisk er for at presse en hurtig udskrivelse igennem. Så har de et problem i kommunen, fordi borgeren så skal have mere hjoelp end aftalt. Tit spørger han, hvad de mener med, at situationen er uoendret, for at tjekke, om deres vurdering er $i$ overensstemmelse med det, der står i systemet. Det er som om, de på hospitalet tror, at de i hjemmeplejen bare holder fri, når borgeren er indlagt. Nå, han må hellere komme videre med Gerdas udskrivelse. Han kan se i systemet, at hun får praktisk hjoelp fra en privat leverandør. Mon hun skal fortsaette med det? Bare de brugte Foelles Sprog, som er det system, kommunen prøver at efterleve. Så tror han, at de bedre kunne forstå hinanden. Han ved godt, at det er svoert med Foelles Sprog-kategorierne $i$ det elektroniske system - også for sygeplejerskerne og plejegrupperne i kommunen. Han synes også, det er et problem, at der ikke kan sendes besked tilbage til hospitalet. Det er ret 
irriterende, isaer fordi han så bliver nødt til at ringe til afdelingen. Det er ikke altid lige let, for han fär sjoeldent fat $i$ en sygeplejerske, som kender patienten. Hun eller han kan oftest kun loese op, hvad der står i hospitalets journal, og det kan han ikke altid bruge til noget. Ofte bliver det til en samtale, hvor de hver isaer holder på deres, og hvor det er helt tydeligt, at de ikke har samme forstålse af, hvad der er bedst for borgeren. Nogle gange kommer de helt op i det røde felt. Det er som om, de på hospitalet bare vil have borgeren hjem uden at toenke på, at det skal voere en godt tilrettelagt udskrivelsesforløb for borgeren. De kender heller ikke altid den regionale sundhedsaftale, hvor der står hvilke tidsfrister, der er goeldende. De tror, at bare fordi deres overloege har bestemt, at borgeren skal udskrives, så kan det ske. Det virker som om, hospitalet ikke ved, hvad der foregår - eller hvilke muligheder kommunen har for at leve op til de forventninger både hospital, de pårørende og patienten har. Ole ved, at det er vigtigt for kommunalbestyrelsen, at kommunen har et godt ry, og at udskrivelsen foregår $i$ overensstemmelse med det, kommunen lover borgerne, og at der ikke kommer klager fra borgerne eller oeldrerådet. Og så selvfølgelig at budgetterne overholdes. Ole loegger Gerdas udskrivelsespapirer $i$ OBS-bunken. Så må han ringe til hospitalet og få svar på sine spørgsmål. Men han ved godt, at han ikke skal ringe for efter halv ti, hvis han skal gøre sig håb om at tale med en sygeplejerske, der ved noget om Gerdas situation.

\section{Spændinger der har betydning for visitatorens arbejde med udskrivelse}

Visitatoren oplever spændinger imellem hospitalets og kommunens forskellige opfattelser af patientens situation. Hans oplevelse er, at sundhedspersonalet på hospitalet ikke anerkender hans arbejdsvilkår: "Det virker som om, hospitalet ikke ved, hvad der foregår - eller hvilke muligheder kommunen har for at leve op til de forventninger, både hospital, pårørende og patient har". Derfor bliver det vigtigt for ham at fastholde sundhedsaftalen, som netop understreger hans formelle magt og dermed ret til at stille krav til hospitalets udskrivelsesprocedure.

Visitatoren har også en formodning om, at de på hospitalet ikke kender til kommunens betingelser eller vilkår, fx hvad kommunen skal stå på mål for overfor sine borgere. Visitatoren skal anvende kommunens standarder for, hvilke ydelser borgeren har krav på. Kommunens standarder bliver til en spænding i samarbejdet med sygeplejersken, fordi hun ikke kender til dem, men udelukkende opfatter visitatorens grundighed som en direkte modstand overfor hende mod at tage patienten hjem.

Der er også knyttet en spænding til visitatorens oplevelse af, at hospitalssektoren tror, at de i kommunen ikke gør deres arbejde, som de skal: "De tror, de bare drikker kaf$f e$, når deres borger er indlagt". Ligesom han oplever, at de mange foreløbige udskrivelser som efterfølgende aflyses er en disrespekt overfor hans og hjemmeplejens arbejde. Der er samtidig en spænding vedrørende udvekslingen af informationer imellem de to sektorers elektroniske kommunikationssystemer. Fx er visitatoren usikker på, hvordan hospitalets informationer om patienten skal forstås og tolkes. Dels er det vanskeligt for ham at forstå de informationer, han får fra hospitalet: "De er ikke til at finde hoved og hale i", dels er informationerne ikke tilstrækkelige. I sammenligning med udskrivelseshistorien fra sygeplejerskens perspektiv bliver det tydeligt, at de to medarbejdere på tværs af sektorerne ikke har samme vidensinteresse, og at de informationer, de udveksler igennem det elektroniske kommunikationssystem, ikke er tilstrækkelige for nogen af dem. Når visitatoren mangler informationer, kan han ikke komme videre med sit arbejde, og det bliver dermed den 
anden sektor, som kommer til at definere, hvordan hans arbejdsdag glider.

I sin funktion som visitator giver det anerkendelse fra ledelsen, når der ikke kommer klager fra borgerne, når kommunens budgetter overholdes, og når borgeren får de ydelser, de er berettigede til. Derfor er det vigtigt for ham, at borgeren ved udskrivelsen er så rask og velfungerende som muligt, så borgeren har krav på færre ydelser, hvilket er billigere for kommunen. Det betyder spændinger i forhold til samarbejdet med sygeplejersken, fordi hun ønsker at udskrive patienten så hurtigt som muligt, selvom patienten måske ikke er helt færdigbehandlet og uden hensyntagen til kommunens standarder og økonomi eller til, hvad kommunen har lovet sine borgere. Uoverensstemmelserne giver spændinger: "De holder hver på sit", fordi de har hver deres agenda; de har hver deres logik. Spændingsfeltet er til at tage at føle på, og det genereres først og fremmest af de sektororienterede hensyn. Grundlaget for at tale sammen i telefonen er på forhånd defineret ved, at der er problemer; enten forstås information ikke og/eller den er mangelfuld. Den telefoniske samtale vil naturligt nok være fyldt med spændinger, da samtalen i princippet anses som en unødvendig og forstyrrende handling.

\section{Styringsteknikker og -teknologier der infiltrerer det tværsektorielle samarbejde}

I et forsøg på at begribe, hvordan de ovenævnte spændinger produceres og fastholdes, diskuterer jeg i nedenstående, hvordan det, som Dean (1994) - med henvisning til Foucault - kalder for styringsteknikker og teknologier, leder til aktørernes selvledelse og dermed deres mulighed for at samarbejde tværsektorielt.

I de to fortællinger fremtræder forskellige styringsteknikker og -teknologier, som åb- ner og lukker for særlige subjektpositioner, og som giver aktørerne særlige handlerum. Både sygeplejersken og visitatoren handler ud fra de institutionelle rammer, som er tæt knyttede til NPM-orienterede styringsteknikker og -teknologier, hvor aktørerne trækker på bestemte videnskomplekser i deres forståelse af, hvordan det tværsektorielle samarbejde kan praktiseres - og hvordan de kan handle.

\section{Styring gennem akkreditering og Lean}

Sygeplejerske Trine henviser i den første fortælling til styringsteknikker, som hører ind under begrebet 'akkreditering': "... Afdelingen skal snart akkrediteres, så det er vigtigt, at al dokumentationen er i orden". Akkreditering er en del af Den Danske Kvalitetsmodel (DDKM), hvor hensigten er at sikre ensartet kvalitet. Akkreditering af sundhedsydelser i Danmark varetages af $\mathrm{IKAS}^{2}$, som er en normgivende institution, der opstiller organisatoriske og faglige standarder, som de sundhedsprofessionelle skal leve op til (Lerborg 2008). Hvis organisationen lever op til akkrediteringsstandarderne, som de gennem forskellige survey-procedurer bliver målt på, opnår organisationen en positiv akkreditering ${ }^{3}$. Akkrediteringssystemet er således et system, der har direkte indflydelse på, hvordan sygeplejersken kan prioritere og argumentere for, hvad der er det rigtige for hende at gøre i praksis. Akkreditering igennem DDKM har primært fokus på at akkreditere inden for egen sektor og ikke på tværs af sektorerne. Samarbejdet på tværs af sektorerne om patientens udskrivelse akkrediteres således ikke.

Lean er et andet styringskoncept, som har betydning for, hvordan sygeplejersken kan organisere og praktisere sit arbejde. Lean er oprindeligt udviklet til den amerikanske bilindustri, med det mål at gøre den mere konkurrencedygtig. Leankonceptet består både af en række værktøjer, bestemte 
produktionsprincipper og af en produktions- og ledelsesfilosofi med fokus på flow, reduktion af spild, standardisering og vedvarende forbedringer, hvor kerneværdien er at skabe bedst mulig værdi for kunden (Hasle 2014, 70). Det er et videnskompleks, som er udmøntet i Lean-uddannelse af Leankonsulenter, som skal lære medarbejderne på afdelingerne at fokusere på udvalgte delområder af patientens forløb (Ballé \& Régnier 2007). Både akkrediteringssystemet og Lean-konceptet er styringsteknologier, der trækker på deres egne forklaringsmodeller, vidensformer og metoder, som har betydning for, hvordan sygeplejersken kan forstå, tale om og samarbejde med den anden sektor om udskrivelsen. Det er styringsteknologier, der har deres eget teoretiske fundament og bestemte måder at gøre tingene på, og som henter deres begrundelser i disse vidensformer. Teknologierne fremmer forskellige kapaciteter og kvaliteter, gennem hvilke aktørerne kommer til at opfatte sig selv som passende (Otto 2003).

\section{Styring gennem visitation, fællessprog og BUM}

Funktionen som visitator blev i 1990'erne introduceret i kommunerne som en myndighedsperson, der skulle sikre, at hjemmepleje og serviceydelser tildeles ud fra objektive kriterier og ud fra aftalte ydelser. I 00'erne blev dette fulgt op af BUM-modellen, hvor det generelle serviceniveau blev fastsat af kommunalbestyrelsen, og hvor beslutninger vedr. plejearbejdets kvalitet, type, omfang og tidsforbrug blev standardiseret (Kamp et al. 2013; Møller 2014; Pedersen \& Hammer 2012). Denne standardisering har både betydet opsplitning af arbejdet i en række delelementer og indførelse af Fælles Sprog i kommunerne. Fælles Sprog er et styringsværktøj, der gennem et standardiseret ydelseskatalog skal sikre en fælles forståelse, der kan føre til ens regi- strering og visitering af ydelser til borgeren (Poulsen 2002; Ryberg 2012). Det er dette videnskompleks, som visitatoren skal trække på, når han prioriterer sine arbejdsopgaver i relation til patientens udskrivelse. Som visitator skal han forholde sig objektivt til borgeren og følge de konkrete anbefalinger i Fælles Sprog-guiden.

\section{Styring gennem tværsektorielle sundhedsaftaler}

Målsætningen om, at der skal aftales regionale sundhedsaftaler om samarbejdet mellem kommunerne og regionerne, fremgår af sundhedsloven (Ministeriet for Sundhed og forebyggelse 2010). Sundhedsloven fastlægger, at der i et samarbejde mellem regionsrådene og kommunalbestyrelserne skal nedsættes et sundhedskoordinationsudvalg, der skal varetage den henholdsvis kommunale- og regionale indsats på sundhedsområdet, herunder indsatsen for at skabe sammenhængende patientforløb mellem sektorerne (Sundhedsstyrelsen 2006). Aftalerne varer tre år, og der er fra sundhedsstyrelsen prioriteret særlige indsatsområder og tværgående temaer, som skal være prioriteret i den regionale sundhedsaftale. Det er aftaler, der godkendes og monitoreres af sundhedsstyrelsen. Også her er det et system bestående af vejledninger og retningslinjer, hvor det bl.a. er beskrevet, hvordan udskrivelsen af borgeren skal foregå, og hvem der har ansvaret for hvilke opgaver hvornår. Både sygeplejersken og visitatoren forsøger at handle med afsæt $\mathrm{i}$ sundhedsaftalens bestemmelser, men det er tydeligt,, at det ikke resulterer i et konkret samarbejde.

\section{Styring gennem selvledelse}

Som Otto fremhæver, former styringsteknologier bestemte subjektformer, som den enkelte må anerkende og tage på sig (Otto 2003, 4). De ovennævnte forskellige sty- 
ringsteknologier sætter sig igennem i de måder, hvorpå både sygeplejersken og visitatoren kan forstå og tænke om sin egen og den andens praksis i forhold til det tværsektorielle samarbejde. De tager så at sige de forskellige teknologier og de mulige forståelsessæt og handlemåder på sig. Styringsteknologierne sætter sig dermed igennem med bestemte rationaler, som ubemærket former selvfølgelige selvledelsesstrategier hos både sygeplejersken og visitatoren. Deres bevidsthed om, hvad der er 'det rigtige at gøre' - deres selvledelse, er således knyttet til de lokale sektorbestemte effekter af NPM. Med denne form for selvledelse bliver de både produceret af og producenter for og fastholdt i, hvordan det tværsektorielle samarbejde om patientens udskrivelse kan foregå. Og på trods af ønsket om det modsatte, er de dermed med til at fastholde de rammer og betingelser, der gør det tværsektorielle samarbejde vanskeligt.

\section{Paradokser i det tværsektorielle samarbejde}

Ovenstående viser, hvordan NPM-orienterede styringsformer, som kan udspille sig på uforudsigelige måder, gør det vanskeligt for de sundhedsprofessionelle at samarbejde tværsektorielt om at skabe et sammenhængende patientforløb. Det er tydeligt, hvordan de gennem teknologier og teknikker ledes til selv at fastholde et sektoropdelt blik på samarbejdet om patientens udskrivelse. Jeg vil nu afslutningsvis diskutere de paradokser, der bliver til i det tværsektorielle samarbejde, når disse styringsteknologier og teknikker leder på de professionelles selvledelse.

\section{Det konkrete kendskab til patienten er fraværende}

Det er et paradoks, at der er en stærk italesættelse af, at patienten skal have op- levelsen af at være en del af et sammenhængende sundhedsvæsen, samtidig med at kendskabet til den konkrete patient er fraværende. Både sygeplejersken og visitatoren henviser i fortællingerne til, at de ikke personligt kender patienten, der skal udskrives. Deres personlige kendskab til patienten synes ikke at være afgørende for deres arbejdsfunktioner omkring patientens udskrivelse. Når visitatoren ringer ind for at få yderligere oplysninger, får han fat i en person, der ikke nødvendigvis kender patienten. Når sygeplejersken taler med visitatoren oplever hun, at han taler ud fra standardiserede skemaer og ikke kender patienten. Det er også tydeligt, at sygeplejersken bliver målt og vurderet på, hvor hurtigt hun kan udskrive patienten og ikke på hendes kendskab til den konkrete patients situation. Faktisk kan hun opleve det som "forstyrrende" at kende til patientens helhedssituation, fordi patienten kun behandles for den indlæggende diagnose - og ikke for sine eventuelle andre lidelser. Dette står i modstrid med idealet om at tage udgangspunkt i den enkelte patients behov, som er en del af den politiske dagsorden (Regeringen 2013b). Når visitatoren ringer til hospitalsafdelingen for at få uddybet informationerne om patienten, ser det umiddelbart ud som om, han efterspørger viden, som tager afsæt $\mathrm{i}$ et personligt kendskab til den konkrete patient. Men også han kan 'klare' sig uden et personligt kendskab til Gerda Hansen. Hans spørgsmål tager afsæt i Fælles Sprog-standarderne, som primært er orienteret mod patientens funktionsniveau, som er det, der giver patienten ret til pleje og serviceydelser. Det er derfor interessant, at de, på trods af de selv kan løse opgaven uden et personligt kendskab til patienten, begge to efterspørger, at den anden part har et personligt kendskab til patienten. Det kommer frem i fortællingerne, når sygeplejersken fremhæver, at visitatoren sidder 
med sine skemaer og ikke synes at kende patienten, og når visitatoren fremhæver, at når han taler med hospitalet, er der ingen, der kender patienten - underforstået, at det burde de. Det kan tyde på, at de begge har en forestilling om, at kendskabet til patienten er vigtigt, om end det ikke er muligt for dem at praktisere det i deres egen praksis.

\section{Et fragmenteret og sektoropdelt sundhedsvasen}

Den politiske målsætning om, at patienterne skal have oplevelsen af et sammenhængende sundhedsvæsen, er et paradoks, når sundhedsvæsnet på mange måder er fragmenteret og sektoropdelt (Seemann et al. 2011). Muligheden for, at de sundhedsprofessionelle skal kunne samarbejde på tværs af sektorerne, er begrænset af, at det er to adskilte sektorer med hver deres organisering, hvor medarbejderne kender meget lidt til hinandens praksis. Vi har i dag et sundhedsvæsen, der primært er bygget op omkring de lægemedicinske specialer og organiseret i en primær og sekundær sektor. Det betyder for det første, at det kan være vanskeligt at behandle patienter med flere sygdomme, som fortællingerne illustrerer, fordi den afdeling som patienten er indlagt ofte kun har blik på én af patientens sygdomme (Seemann, Dinesen \& Gustafsson 2013). For det andet er samarbejdet primært organiseret ud fra en form for silotænkning, hvor de sundhedsprofessionelle først og fremmest kan tænke inden for egen sektors muligheder og begrænsninger i samarbejdet (se fx Klausen 2010; Seemann et al. 2011). For det tredje viser mine analyser, at samarbejdet organiseres med forskellige sektordefinerede styringsformer, som leder de professionelles selvledelse på måder, der netop ikke understøtter målsætningen om et sammenhængende patientforløb. Dette på trods af at det siden 70'erne har været et centralt tema på den politiske dagsorden at tale om at styrke et sammenhængende patientforløb på tværs af sektorgrænser (se fx Indenrigsministeriet 1985; Regeringen 1994; 2013b). At problemerne med at skabe et sammenhængende sundhedsvæsen stort set har været italesat på den samme måde i årtier understreger, at det er en yderst kompleks og vanskelig problemstilling.

\section{Udskrivelsessituationen en kampplads}

Endelig er det et paradoks, at udskrivelsessituationen fremstår som en kampplads, hvor de sundhedsprofessionelle, med afsæt i hver deres NPM-logikker, kæmper mere om retten til at definere patientens plads end et mødested, hvor de kan samarbejde om at skabe et sammenhængende udskrivelsesforløb for patienten. Som beskrevet ovenfor er der ingen af parterne, som anspores, anerkendes eller belønnes for et tværsektorielt samarbejde - tværtimod. Udskrivelsessituationen bliver til en kampplads, hvor de begge er tvunget til at tænke på deres egen sektors logikker. På sygehuset handler det om, at patienten skal udskrives hurtigst muligt, og i kommunen om, at borgeren ved udskrivelsen skal have et så godt funktionsniveau som muligt - og dermed behov for færre ydelser. Selvom medarbejderne agerer ud fra de mulige institutionelle rammer, bliver det dem som personer, der kommer til at mærke den dårlige stemning, mistroen og modstanden fra den anden part. Det får, som fortællingerne viser, betydning for deres tværsektorielle samarbejde. Det sammenhængende patientperspektiv er en politisk beskrevet målsætning, men de forskellige institutionelle rammer, styringsteknologier og teknikker gør det meget vanskeligt for de sundhedsprofessionelle at agere ud fra denne fælles politiske målsætning. 


\section{Konklusion og perspektivering}

I denne artikel har jeg, med afsæt i genereret viden fra et gennemført aktionsforskningsprojekt, illustreret, hvordan det tværsektorielle samarbejde imellem de sundhedsprofessionelle omkring patientens udskrivelse fra hospitalet bliver vanskelig, når sektorforskellige NPM-orienterede styringsteknikker og -teknologier sætter rammerne for, hvordan de sundhedsprofessionelle kan samarbejde. Og jeg har vist, at de institutionelle rammers magt og vidensformer, som de sundhedsprofessionelle arbejder ud fra, $\mathrm{i}$ høj grad kun giver mening og anerkendelse inden for hver deres sektor. Fortællingerne om patientens udskrivelse viser, hvordan spændinger i samarbejdet om udskrivelsen på en gennemgribende facon påvirker de sundhedsprofessionelles arbejdsvilkår og skaber paradokser i det tværsektorielle samarbejde. Det bliver derfor 'det muliges kunst' for de sundhedsprofessionelle at etablere et tværsektorielt samarbejde, som kan understøtte idéen om det sammenhængende patientforløb. Fortællingerne viser desuden, hvordan samarbejdet nærmest bliver forstyrrende for de sundhedsprofessionelle, når de forsøger at samarbejde på tværs af sektorerne.

Med denne artikel bidrager jeg til diskussionen om, hvor åbenlyst problematisk det er at tale om et sammenhængende sundhedsvæsen, når de sundhedsprofessionelle stilles overfor sektoropdelte NPM-orienterede styringsteknologier, som også sætter sig igennem som selvledelsesstrategier. På trods af gode hensigter i politiske og administrative dokumenter, reformforslag og retningslinjer om at styrke det tværsektorielle samarbejde, synes det umuligt, fordi der ikke er fokus på betydningen af de institutionelle rammer forskellige videns- og magtformer. Det er oplagt at spørge, om det overhovedet er muligt inden for de nuværende institutionelle rammer og betingelser i sundhedsvæsenet at skabe et godt sammenhængende patientforløb med udgangspunkt i den enkelte patients behov? Hvis det er et oprigtigt ønske at skabe et sammenhængende sundhedsvæsen, så er det ikke, som fremhævet i indledningens citater, tilstrækkeligt at styrke indsatsen for, at de sundhedsprofessionelle bedre kan deres tværsektorielle samarbejde. Det er derimod nødvendigt at forske yderligere $\mathrm{i}$, hvordan der kan skabes konkrete rammer, der på tværs af sektorerne gør det muligt for de sundhedsprofessionelle at samarbejde om at skabe et sammenhængende forløb til gavn for patienterne.

\section{Noter}

1 Primærsektor omhandler sundhedsaktiviteter, der udføres af praktiserende læger, hjemmepleje og andre sundhedsaktiviteter, der ikke foregår i hospitalsregi. Sekundærsektoren varetager samtlige sundhedsaktiviteter, der foregår i hospitalsregi.

2 IKAS http://www.ikas.dk/forside/

3 http://www.ikas.dk/ddkm/hvad-er-akkreditering/

\section{ReferenCER}

Agar, Michael (1990): Text and Fieldwork Exploring the Excluded Middle, Journal of Etnography 19, 1

Andersen, Tom (1987): The Reflecting Team: Dialogue and Meta-Dialogue in Clinical Work, Family Process 26, 4, 415-28

Bacchi, Carol (2009): Analysing Policy, Pearson, E-book

Ballé, Michael \& Anne Régnier (2007): Lean as a Learning System in a Hospital Ward, Leadership in Health Services 20, 1, 33-41

Busch, Tor et al. (2005): Modernisering Av Offentlig Sektor, 2.udgave ed. Universitetsforlaget Coghlan, D. \& T. Brannick (2014): Doing Action Research in Your Own Organization, $4^{\text {th }}$ Edition, Sage, E-book 
Dahl, H. M. (2004): A View from the Inside: Recognition and Redistribution in the Nordic Welfare State from a Gender Perspective, Acta Sociologica 47, 4, 325-37

Dahl, H. M. (2009): New Public Management, Care and Struggles about Recognition, Critical Social Policy 29, 4, 634-54

Danske Regioner (2015): Kommissorium for Udvalg Om Det Naere Og Sammenhaengende Sundhedsvoesen, http://www.regioner.dk/ sundhed/tema+det+sammenhængende+sun dhedsvæsen

Dean, Mitchell (1994): A Social Structure of Many Souls: Moral Regulation, Government, and Self-Formation on JSTOR, The Canadian Journal of Sociology, 19, 2

Dean, Mitchell (2002): Critical And Effective Histories: Foucault's Methods and Historical Sociology, London and New York, Routledge

Foucault, Michel (1972): The Archaeology of Knowledge, London, Routledge

Foucault, Michel (1980): Talens Forfatning, Rhodos

Foucault, Michel (1982): The Subject and Power on JSTOR, University of Chicago Press, 8, 4, Retrieved March 1, 2016

Foucault, Michel (2012) The Birth of the Clinic, London, Rougtledge

Foucault, Michel (2014): On The Government of the Living, Palgrave Macmillan

Greve, Carsten (2003): Public-Private Partnerships in Scandinavia, International Public Management Review 4, 2, 59-69

Halkier, B. (2010): Focus Groups as Social Enactments: Integrating Interaction and Content in the Analysis of Focus Group Data, Qualitative Research 10, 1, 71-89

Hasle, Peter (2014): Lean Og Professionel Autonomi På Hospitaler, Tidskrift for Arbejdsliv, $1,67-82$

Hee Pedersen, Christina (2008): Anchors of Meaning - Helpers of Dialogue: The Use of Images in Production of Relations and Meaning, International Journal of Qualitative Studies in Education 21, 1,35-47

Holliday, Adrian (2016): Doing \& Writting Qualitative Research, 3, New Delhi, SAGA Publications Inc., E-book

Hood, Christopher (1991): A Public Manage- ment For All Seasons, Public Administration 69, 3-19

Høgsgaard, Ditte (2015): Aktionsforskningen på arbejdet, Sygeplejersken 2/7/2015, 115, 14, 81-86

Høgsgaard, Ditte (2016): Så længe personalet er syndebuk, kommer patienten ikke i centrum, Information 10. maj 2016

Indenrigs- og Sundhedsministeriet (2004): Aftale Om Strukturreform

Indenrigs- og Sundhedsministeriet (2007): Kommunalreformen - Kort Fortalt.

Indenrigsministeriet (1977): Betoenkning Om Grundlaget for En Overordnet Prioritering Af Indsatsen Inden for Sygebehandling Og Sygdomsforebyggelse

Indenrigsministeriet (1985): Samordning I Sundhedsvæsenet. Betænkning Fra Det Af Indenrigsministeren Nedsatte Samordningsudvalg for Sundhedsvæsenet, Betaenkning Nr. 1044

Jespersen, Peter Kragh (2005): The 18th Scandinavian Academy of Management (NFF) Meeting at Aarhus School of Business in Denmark, (August), 1-28

Jungk, Robert \& Robert R. Müllert (1984): Robert Jungk \& Norbert Müllert: Håndbog I Fremtidsvoerksteder, Politisk revy

Kamp, Annette et al. (2013): New Public Management: Konsekvenser for Arbejdsmiljø Og Produktivitet, Skriftserie for Center for arbejdslivsforskning, 3

KL (2012): Det Noere Sundhedsvoesen Kommuneforlaget $\mathrm{A} / \mathrm{S}$

KL (2015): Sammen Om Sundhed, Kommuneforlaget A/S

Klausen, Kurt Klaudi (2010): Koncernledelse I Det Offentlige - Nu Også I Kommunerne?, Ledelse \& erhvervsøkonomi 2, 7-24

Lerborg, Leaon (2008): KORA - Akkreditering Bureaukratiseret Tillid, Krevi

Ministeriet for Sundhed og forebyggelse (2010): Bekendtgørelse Af Sundhedsloven, $L B K$ nr 1202 14/11/2014 2014 (1202), Afsnit 1, Kaptiel 1

Møller, J. L. et al. (2014): Omsorg På Markedsvilkår - Arbejdsvilkår Og Orienteringer I Den Fragmenterede Danske Hjemmepleje, Tidskrift for arbejdsliv 4, 85-102

Neidel, Agnete (2011): På Vej ?! Kritiske Analyser 
Af Recorveri-Orientering Af Det Socialpsykiatriske Arbejde

Otto, L. (2003): Govermentalitetsteori Styringsteknologi Og Subjektet, Arbejdspapir 1. udkast.

Pedersen, John Storm \& Sverri Hammer (2012): Nogle Konsekvenser Af Strukturreformen År 6 - Det Specialiserede Socialområde, Tidsskrift for Arbejdsliv 14, 4, 48-67

Phillips, L. J. (2011): Analysing the Dialogic Turn in the Communication of Research-Based Knowledge: An Exploration of the Tensions in Collaborative Research, Public Understanding of Science 20, 1, 80-100 Phillips, Louise (2011): The Promise of Dialogue, 1st ed. Amsterdam: John Benjamins Publishing Company

Phillips, Louise et al. (2013): Knowledge and Power in Collaborative Research: A Reflexive Approach

Poulsen, Mette Vinther (2002): Voerd at Vide Om Foelles Sprog, Kommuneinformation

Reason, Peter and Hilary Bradbury (2008).: The SAGE Handbook of Action Research, E-Book

Regeringen (1994): Patienten I Centrum

Regeringen (2013a): Bedre Kvalitet Og Samarbejde-Opfølgning På Evaluering Af Kommunalreform, www.oim.dk.

Regeringen (2013b): Mere Borger Mindre Patient - et Stærkt Fælles Sundhedsvæsen, 1-48

Rose, Nikolas \& Peter Miller (1992): Political
Power beyond the State. Problematics of Governement, British Journal of Sociology 43, 2, 173-205

Ryberg, Marie (2012): Forundersøgelse I Projektet Tværgående Ledelse På Ældreområdet, CBS Rapport

Seemann, Janne, Birthe Dinesen \& Jeppe Gustafsson (2013): Interorganizational Innovation in Systemic Networks: TELEKAT Findings, Innovation Journal 18, 3, 2-19

Seemann, Janne, Jeppe Gustafsson \& Birthe Dinesen (2011): Interorganisatoriske Ledelsesudfordringer : Afsæt I Erfaringer Fra TELEKAT (december), 1-19

Skrubbeltang, Jørgen (2014): Fra Øjenvidne Til Jeg-Vidne, Ph.d.-afhandling, Roskilde Univseristet

Sundheds- and Ældreministeriet (2016): Sundheds- Og Ældreministeriet, Minister Diskuterer Visioner for Det Nære Sundhedsvæsen - Sum.dk., Hjememside Nyheder

Sundhedsstyrelsen (2006): Vejledning Om Sundhedskoordinationsudvalg Og Sundhedsaftaler

Svensson, L. \& Kurt Aagaard Nielsen (2006): Action Research and Interactive Research. Beoynd Theory and Practice, Shaker publishing, E-Book

Taylor, Stephanie (2009): Narratives of Identity and Place. London and New York, Routledge

Tak til forskningsgruppen Dialogisk Kommunikation ved Institut for Kommunikation og Humanistisk Vidensskab, RUC for inspirende diskussioner og input til denne artikel. Tak til de to reviewer og til medredaktør Sofie Sauzet, Tidskriftet Nyt om Arbejdsliv for inspirerende brugbar feed back.

Ditte Høgsgaard, ph.d.-studerende ved Institut for Kommunikation og Humanistisk Videnskab (IKH) Roskilde Universitet

e-mail:diho@ruc.dk 